\title{
Family Business: Evaluation of the Support System and Development
}

\author{
Kuvandikov Shuhrat Oblokulovich, \\ Samarkand Institute of Economics and Service \\ Samarkand, Uzbekistan \\ Email: shuhratq@rambler.ru
}

Received: March 13, 2021. Revised: April 1, 2021. Accepted: April 4, 2021. Published: April 5, 2021.

\begin{abstract}
This article examines the progress made in strengthening the legal framework for family entrepreneurship in Uzbekistan, and the criteria for assessing the effectiveness of their support system. At the same time, factors influencing the effectiveness and development of family business were evaluated using econometric methods. Also developed scientific-practical recommendations and conclusions aimed at the development of family business in the regions.
\end{abstract}

Keywords - assessment, development factors, effectiveness, efficiency, family entrepreneurship, state support system, system of indicators.

\section{INTRODUCTION}

$T^{t}$ is well-known that increasing the effectiveness of the 1 family business support system is important in the socioeconomic development of the regions. The development of family entrepreneurship makes a significant contribution to meeting the needs of the population in goods and services, the formation and growth of GRP, and most importantly, ensuring employment and welfare of families [11]. Therefore, with the support of family entrepreneurship, special attention is paid to strengthening their role and role in the national economy as well as their legal framework. In this regard, Article 23 of the Law of the Republic of Uzbekistan "On family entrepreneurship"[1] is specifically aimed at supporting family entrepreneurship. The purpose of supporting family businesses is to protect them from various risks. According to the ongoing reforms in our country, the system of support for family business includes [2]:

- Regulatory legal acts aimed at support and development of small business and family entrepreneurship;

- Government agencies responsible for managing the infrastructure and support of public policy in the area of development of small business and family entrepreneurship;

- State and non-governmental and commercial organizations, which are aimed at the development of small business and family entrepreneurship.

The effectiveness of such a support system includes simplification of licensing procedures in entrepreneurial activity, tax system reform, abolition of planned inspections not related to financial and economic activities of business entities. However, the measures undertaken in these areas are still insufficient. The Decree of the President of the Republic of Uzbekistan "On Measures to Radically Improve the System of Support and Protection of Entrepreneurship" (May 14, 2019), aimed at addressing these issues, states that there are several negative factors associated with the wider involvement of the population in entrepreneurial activity [3]. The existence of such problems requires an assessment of the effectiveness and development of the family entrepreneurship support system.

The effectiveness of the family business support system requires the integration of the numerous organizational structures that create it. Thus, the hypothesis that the development of family entrepreneurship depends on the effectiveness of the support system is appropriate. Accordingly, we took a scientific approach to the problem under study and decided to study methodological aspects of assessing the effectiveness and development of the family entrepreneurship support system in the regions.

The economic literature has different methodological approaches to assessing the support and development of small businesses $[8,10,12,13,14]$. In this regard, S. Popov believes that when evaluating public programs, it is necessary to follow the principle of the multiplier effect. That is, the implementation of program objectives should also address other socio-economic issues [8]. In essence, the development of small businesses increases employment and income levels, and growth in incomes leads to increased demand for goods and services, which in turn increases supply. Thus, successive and interdependent solution of these tasks will lead to the ultimate goal - socio-economic development of the regions and improvement of the quality of life of the population.

We reasoned that the essence and methodology of such approaches do not serve as a common methodology for assessing the family entrepreneurship support system. This is because the object studied has its own independent organizational and legal status of economic activity. Therefore, we have developed an assessment of the effectiveness of its support system.

\section{METHODOLOGY}

There are many factors that influence the development of the family business. We think it is advisable to highlight some of them in order to approach the chosen methodologically. Factors influencing the development of family entrepreneurship were investigated using multivariate correlation-regression analysis. This was followed by data 
from families in various parts of the Samarkand region. This observation was examined in the following areas of the family business in the service sector:

- Trade and catering services (retail, national cuisine, and restaurants);

- National crafts and repair workshops;

- Computer and modern information technology services (internet cafes, small print houses, mobile services, and payment);

- Transportation services (freight and transportation services to the public);

- Factors affecting the income of families engaged in barbershops and beauty salons (renting bridal dresses and wedding equipment, etc.) have been studied.

Studies have shown that the following factors can influence the development of family entrepreneurship:

- $x_{1}$ - tax rate;

- $x_{2}$ - annual refinancing rate;

- $\quad x_{3}$ - single social payment from the payroll fund;

- $u$ - unacceptable factors;

- $\quad y$ - development of family business.

The correlation analysis method was used to determine the effect of these factors on the outcome designation. This is calculated by calculating the pair correlation coefficient. This method allows us to exclude overlapping factors that are overlapping and the weakest link to the resulting character. Then a multivariate regression equation is constructed using regression-correlation methods.

The significance of the factors involved in the designation of the regression equation is evaluated in the design of the regression equation. For this, the correlation strength of all the factors was calculated, and the factors that are weaker linking with the overlapping result character are subtracted from the equation.

Our theoretical model, which expresses the influence of these factors on the outcome designation, was in the form of a linear regression equation (1). The linearity of the function was determined by the Ramsey test in Gretl's software.

$$
\gamma=\beta_{0}+\beta_{1} x_{1}+\beta_{2} x_{2}+\beta_{3} x_{3}+u
$$

Accordingly, factors 1 and 3 had a significant effect on the change in the outcome designation and the other factors were not significant. It was found that the net gain in all types of regression equivalents depends on all factors. In this connection, the coefficient of determination was as follows:

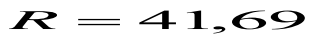

Determination coefficient shows that $41.69 \%$ of net income depends on the single social payment from the tax and payroll fund.

Our rated model looks like this (2):

$$
\gamma=2,35-0,28 x_{1}-1,68 x_{3}
$$

The elasticity coefficient was calculated to determine the economic nature of the resulting equation. Accordingly, a 1\% reduction in the single tax rate, an increase of net income by $0.28 \%$, and a $1 \%$ reduction of the single social payment from the payroll fund will result in an increase of net income by $1.68 \%$.

\section{RESULATS}

In recent years in the country based on strengthening the legal basis of family entrepreneurship, several positive results have been achieved, including:

- The legal framework for the family business was created in accordance with the Law on Family Entrepreneurship of April 26, 2012;

- "Family Entrepreneurship Support Centers" were established in the regions, districts and cities in accordance with the Decree of the President of the Republic of Uzbekistan "On Additional Measures to Engage Entrepreneurship in the Regions and Develop Family Entrepreneurship";

- State Program "Every family - entrepreneur", adopted by the Presidential Decree No. UP-5468 of 29 June 2018 "Concept of improvement of tax policy of the Republic of Uzbekistan" of the Cabinet of Ministers of the Republic of Uzbekistan dated August 22, 2017, additional measures for financing of projects, providing microfinancing of subjects, creation of new workplaces and provision of microfinance services to poor families According to the law No. 655 on the formation of the initial capital to start a business, family activities, expansion of the tax credit and a number of benefits. Expansion and attraction of foreign investments and loans also opened;

- The organization of family business in the sphere of services and crafts, the Cabinet of Ministers of the Republic of Uzbekistan dated August 7, 2018 "On the organization of family guest houses" and July 29, 2009 "Family entrepreneurship and craftsmanship without forming a legal entity". Decree of the President of the Republic of Uzbekistan "On measures to develop and expand family business";

- Provided preferential legal guarantees in the creation of new jobs and labour relations. By the Decree of the President of the Republic of Uzbekistan dated July 14, 2018 No PP-3856 "On Measures to Improve and Increase Efficiency in Employment of the Population", regional funds to create new jobs were created; According to the Decree of the President of the Republic of Uzbekistan dated January 5, 2006 "On measures to stimulate the expansion of cooperation between large industrial enterprises and services based on the development of home-based work" and "Regulations on home-based work," the right to award pensions was provided;

- By the Resolution of the Cabinet of Ministers "On cardinal improvement of the system of registration procedures for the organization of entrepreneurial activity" simplified mechanisms of state registration of business entities and issuance of permits for business activities were introduced. 
Based on these regulatory documents, the financial support for small business and family entrepreneurship by the end of 2018 will amount to 30648.8 billion sums. 668,4 billion sums was allocated for the development of family business and crafts. some [5] or $21.8 \%$ of total loans provided. During the same period, commercial banks of the Samarkand region provided 101 billion 699 million sums of loans to 4723 projects under the "Every Family - Entrepreneur" program [6]. As a result, the number of newly established business entities increased by 2.3 times [3]. The state programs aimed at support of family businesses have given their socio-economic effect and create great opportunities for the economic development of the country. This aspect is most evident in macroeconomic indicators (Table 1).

Table 1.

The role of family business in the economy of Uzbekistan

\begin{tabular}{|l|c|}
\hline \multicolumn{1}{|c|}{ Indicators } & $\mathbf{2 0 1 7}$ year \\
\hline Number of family businesses, (units) & 12184 \\
\hline Share in operating enterprises (in percent) & 3,9 \\
\hline $\begin{array}{l}\text { jobs created at the expense of family } \\
\text { business, (thousand) }\end{array}$ & 358,56 \\
\hline $\begin{array}{l}\text { Net sales of family businesses' products } \\
\text { (million soums) }\end{array}$ & 679320,3 \\
\hline $\begin{array}{l}\text { Net proceeds from sales of products per } \\
\text { one family enterprise, (million soums) }\end{array}$ & 141,8 \\
\hline $\begin{array}{l}\text { property and entrepreneurial incomes in the } \\
\text { family income, (\%) }\end{array}$ & 55,2 \\
\hline $\begin{array}{l}\text { Share of family investment in fixed assets, } \\
\text { in\% }\end{array}$ & $\begin{array}{l}12,6 \% \\
(8.962 \\
\text { billion } \\
\text { soums) }\end{array}$ \\
\hline Deposits in banks in relation to GDP, (\%) & 12,4 \\
\hline
\end{tabular}

Source: www.stat.uz - Created by the author based on the data from the State Committee on Statistics of Uzbekistan

According to the econometric analysis, tax and social payments are an important factor in the effectiveness of family businesses. This, in turn, requires the payment of taxes and social benefits from the net proceeds from these activities [7]. This aspect is most clearly reflected in the tax reform in our country. According to the new tax concept [4], family businesses' payments to the budget were set at $8 \%$ as of January 1,2019 , when the single tax in catering was $10 \%$ of total revenue in 2018. In manufacturing, it is 5\% and $4 \%$ respectively. Also, social payments were reduced from $15 \%$ in 2018 to $12 \%$ in 2019 . This shows that the effectiveness of the family entrepreneurship support system is directly related to payments to the budget.

\section{CONCLUSIONS}

- The methodological approach to the topic concluded that the criteria for assessing the effectiveness and development of the family entrepreneurship support system in the regional economy are reflected in the socio-economic performance of family businesses and the indicators related to employment and welfare.

- In assessing factors of family business development, the factors influencing its effectiveness were identified. At the same time, the econometric analysis of the factors affecting the net income of family businesses operating in the service sector was developed and a mathematical model was developed;

- The effectiveness and efficiency of the family entrepreneurship support system are its benchmarks. Therefore, the essence of each of the concepts of "effectiveness" and "efficiency" as applied to the problem under investigation was revealed. Accordingly, the effectiveness of the family entrepreneurship support system is the ratio of the results achieved through the implementation of targeted state programs to expenditures from all sources. Also, the efficiency of the family entrepreneurship support system is related to the implementation of government programs and reflects the degree to which the program has achieved its objectives. The difference between efficiency and effectiveness is that it is a relative value and is characterized by the ratio of the cost to the result. In other words, efficiency reflects the complex economic and social relationships associated with achieving the highest results from limited resources.

The proposed methodological approach will help government agencies to draw conclusions and measures on the role and place of family entrepreneurship in the regional economy. It also plays an important role in defining the priorities of the regional economy and in developing effective measures [9]. From this point of view, the evaluation of family entrepreneurship development is of great conceptual importance.

\section{REFERENCES}

[1] The Law of the Republic of Uzbekistan "On Family Entrepreneurship" (April 26, 2012).

[2] Decree of the President of the Republic of Uzbekistan On the strategy of further development of the Republic of Uzbekistan. (February 7, 2017) № 4947.

[3] Decree of the President of the Republic of Uzbekistan "On Measures to Radically Improve the System of Support and Protection of Entrepreneurship" (May 14, 2019).

[4] State Tax Committee of the Republic of Uzbekistan. Tutorial on changes to tax legislation for 2019. T.: - 2018, pp. 77.

[5] Statistical bulletin of the Central Bank of the Republic of Uzbekistan, Tashkent, 2019 (www.cbu.uz/uzc/publikacii/buleten/)

[6] Samarkand Regional Department of the Central Bank of the Republic of Uzbekistan.

[7] Abu-Mostafa, Y. S., \& Atiya, A. F. (1996). Introduction to financial forecasting. Applied intelligence, 6(3), 205-213.

[8] Popov, S. A. (2013). Comprehensive analysis of the evaluation of the effectiveness of management of small business support programs. Fundamental research.-2013, 10, 2249-2252.

[9] Popovich, Nenad N., and Anna Viktorovna Bogomolova. "Overcoming regional imbalances. The experience of Russia, Serbia and some EU countries." (2010).

[10] MacMahon, J., \& Murphy, E. (1999). Managerial effectiveness in small enterprises: Implications for HRD. Journal of European Industrial Training.

[11] Schumpeter, J. A. (2017). Theory of economic development. Routledge.

[12] Foreman-Peck, J. (2013). Effectiveness and efficiency of SME innovation policy. Small Business Economics, 41(1), 55-70.

[13] Size Standards. URL: http://www.sba.gov/content/size-standards.

[14] Small and micro enterprises. URL: http://www.ec.europa.eu/enterprise/

\section{Creative Commons Attribution License 4.0 (Attribution 4.0 International, CC BY 4.0)}

This article is published under the terms of the Creative Commons Attribution License 4.0 https://creativecommons.org/licenses/by/4.0/deed.en_US 